\title{
Sistem Pendukung Keputusan Dengan metode TOPSIS untuk Menentukan Pemenang Tender Pada Dinas Pekerjaan Umum dan Penataan Ruang Provinsi Bengkulu
}

\author{
Ade Titin Sumarni ${ }^{1}$, Ade Fitrah Putra akhir ${ }^{2}$ \\ 1,2Universitas Prof. Dr. Hazairin, SH Bengkulu, \\ e-mail : adetitin30@gmail.com ${ }^{1}$ adefitrah.af@gmail.com²
}

\begin{abstract}
ABSTRAK : Penelitian ini bertujuan untuk membantu menentukan pemenang tender proyek pada Dinas Pekerjaan Umum dengan cara membuat aplikasi Sistem Pendukung Keputusan dengan menerapkan metode TOPSIS. Aplikasi ini diharapkan dapat mempermudah proses pemilihan pemenang tender proyek tersebut. Dalam penelitian akan membahas masalah yang akan diangkat yaitu membuat dan menghitung variabel pada metode TOPSIS dalam Sistem pendukukung keputusan untuk menentukan pemenang tender pada Dinas Pekerjaan Umum dan Penataan Ruang Provinsi Bengkulu. Waktu dan tempat pengumpulan data dan penelitian dilaksanakan di Dinas Pekerjaan Umum dan Penataan Ruang Provinsi Bengkulu yang beralamatkan Jalan Prof. Dr. Hazairin, SH No. 901 Bengkulu. Penelitian ini menggunakan metode penelitian waterfall. Dimana metode penelitian waterfall ini Terdiri dari perancangan sistem, analisis sistem, desain sistem, pengkodean program, uji coba program, implementasi sistem dan pemeliharaan sistem. Hasil penelitian ini adalah metode TOPSIS dapat diterapkan pada Sistem Pendukung Keputusan pemilihan pemenang tender proyek pada Dinas Pekerjaan Umum Provinsi Bengkulu menggunakan aplikasi visual basic net 2010. Hasil dari penerapan metode ini dalam aplikasi Sistem Pendukung Keputusan memperoleh hasil yang akurat sehingga dapat menentukan pemenang tender proyek pada Dinas Pekerjaan Umum Provinsi Bengkulu.
\end{abstract}

Kata Kunci: Sistem, Pendukung-Keputusan, Tender.

ABSTRACT: This study aims to help determine the winner of a project tender at the Public Works Department by making a Decision Support System application using the TOPSIS method. This application is expected to simplify the process of selecting the winner of the project tender. This research will discuss the problems to be raised, namely creating and calculating variables in the TOPSIS method in the decision support system to determine the winner of the tender at the Bengkulu Province Public Works and Spatial Planning Office. The time and place for data collection and research were carried out at the Bengkulu Province Public Works and Spatial Planning Office which addressed Prof. Dr. Hazairin, SH No. 901 Bengkulu. This study uses the waterfall research method. Where this waterfall research method consists of system design, system analysis, system design, program coding, program testing, system implementation and system maintenance. The results of this study are the TOPSIS method can be applied to the Decision Support System for selecting project tender winners at the Public Works Office of Bengkulu Province using the visual basic net 2010 application. Bengkulu Province Public Works Office.

Keywords: Systems, Decision Support, Tender.

\section{PENDAHULUAN}

Tender adalah tawaran untuk mengajukan harga, memborong pekerjaan atau menyediakan barang yang diberikan oleh perusahaan swasta besar atau pemerintah kepada perusahaan-perusahaan lain. Mengikuti tender adalah salah satu cara untuk mendapatkan kontrak bisnis dalam skala besar atau memperluas usaha anda. Banyak perusahaan yang secara teratur menyelenggarakan tender. Beberapa instansi pemerintah kini bahkan memuat semua tender dan investasi pemerintah di media cetak agar siapapun dapat mengikutinya. Proses tender adalah proses yang penuh persaingan sehingga amatlah penting bagi perusahaan untuk mencantumkan penawaran yang kompetitif di dalam proposal.

Proses untuk mendapatkan proyek dari dinas Pekerjaan Umum dan penataan ruang yaitu melalui tender. Masalahnya dalam pemilihan perusahaan properti yang terkadang tidak tepat karena dalam pemilihan kontraktor yang dilakukan belum menggunakan aplikasi. Padahal banyak aspek yang harus dipertimbangkan dalam pemilihan tersebut. Hal ini menyebabkan perusahaan yang dipilih sebagai pemenang tender terkadang tidak sesuai dengan yang diharapkan. 
Perusahaan yang ingin mengikuti seleksi tender biasanya melakukan pendaftaran menjadi peserta tender yang akan diseleksi oleh dinas Pekerjaan Umum dan penataan ruang. Dalam pemilihan perusahaan properti banyak aspek yang harus dipertimbangkna dan ditambah banyaknya perusahaan yang mendaftar dalam seleksi pemenang tender proyek sehingga Dinas Pekerjaan Umum dan Penataan Ruang membutuhkan waktu yang lama dalam tahapan seleksi pemenang tender. Untuk itu diperlukannya suatu sistem yang bisa mempercepat dan mempermudah kinerja panitia pengadaan Lelang Proyek Pemerintah dengan hasil yang akurat, sehingga pengambil kepuusan dengan menyediakan berbagai alternatif pilihan dengan memperimbangkan beberapa unsur dari setiap kriteria yang sudah ditentukan.

Sistem pendukung keputusan memberikan dukungan untuk memilih suatu keputusan yang kompleks agar mendapatkan keputusan yang paling tepat, cepat dan efisien. Banyak metode yang digunakan dalam sistem pendukung keputusan. Salah satunya metode TOPSIS. Metode TOPSIS telah banyak digunakan dalam menyelesaikan masalah dalam pengambilan keputusan ${ }^{1}$.

Metode TOPSIS dapat digunakan untuk menghitung multi variabel dalam sistem pengambilan keputusan pemilihan perusahaan yang tepat menjadi pemenang tender. Untuk itu penulis tertarik untuk melakukan penelitian tentang bagaimana menerapkan metode TOPSIS dalam sistem pendukung keputusan. Dalam hal ini yaitu menentukan pemenangan tender di Dinas Pekerjaan Umum dan Penataan Ruang.

\section{LANDASAN TEORI}

\section{A. Tender}

Pada dasarnya, tender merupakan tawaran mengajukan harga untuk memborong suatu pekerjaan untuk mengadakan barang-barang atau untuk menyediakan jasa. Tawaran mengajukan harga terbaik untuk membeli atau mendapatkan barang dan atau jasa, untuk menyediakan barang dan atau jjasa, atau melaksanakan suatu pekerjaan.

\section{B. Lelang}

Pelelangan adalah serangkaian kegiatan untuk menyediakan kebutuhan barang / jasa dengan cara mencptakan persaingan yang sehat diantara penyedia barang / jasa yang setara dan memenuhi syarat. Berdasarkan metode dan tata cara tertentu yang telah ditetapkan dan diikuti oleh pihak-pihak yang terkait secara taat asas sehingga terpilih penyedia jasa terbaik.

\section{Proyek}

Proyek merupakan suatu rangkaian kegiatan yang berlangsungdalam jangka waktu terbatas. Dengan alokasi sumber daya tertentu dan dimaksudkan untuk menghasilkan produk yang kriteria mutunya telah digariskan dengan jelas. Proyek dapat pula diartikan sebagai sederetan aktifitas yang diaahkan pada suatu hasil dimana jangka waktu penyelesaiannya ditentukan.

\section{Konsep Sistem Pendukung Keputusan}

Sistem pendukung keputusan merupakan suatu system interaktif yang membantu manajer dalam mengambil keputusan. Melalui penggunaan data dan model keputusan untuk memecahkan masalahmasalah yang sifatnya semi terstruktur ${ }^{2}$.

Mengklasifikasikan system Pendukung Keputusan terdiri dari beberapa komponen yaitu subsistem database, subsistem modelbase, subsistem pengetahuan dan subsistem dialog 6 .

Tujuan dari system pendukung keputusan sebagai berikut :

1. Membantu manajer dalam pengambilan keputusan atas masalah semiterstruktur

2. Meningkatkan efektivitas keputusan yang diambil manajer lebih daripada perbaikan efisiensinya.

3. Peningkatan produktivitas. Pendukung terkomputerisasi bias mengurangi ukuran kelompok dan memungkinkan para anggotanya untuk berasal dari berbagai lokasi yang berbedabeda (menghemat biaya perjalanan ${ }^{3}$.

E. TOPSIS (Teqnique For Order Preferences by Similarity to Ideal Solution)

TOPSIS adalah salah satu metode pengambilan keputusan multikriteria yang pertama kali diperkenalkan oleh Yoon dan Hwang (1981) ${ }^{4}$. TOPSIS menggunakan prinsip bahwa alternatif yang terpilih harus mempunyai jarak terdekat dari solusi ideal negatif dari sudut pandang geometris dengan menggunakan jarak euclidean untuk menentukan kedekatan relatif dari suatu alternatif dengan solusi optimal. Solusi ideal positif didefinisikan sebagai jumlah dari seluruh nilai terbaik yang dapat dicapai untuk setiap atribut, sedangkan solusi negatif-ideal terdiri dari seluruh nilai terburuk yang dicapai untuk setiap atribut. TOPSIS mempertimbangkan keduanya, jarak terhadap solusi ideal positif dan jarak terhadap solusi ideal negatif dengan mengambil kedekatan relatif terhadap solusi ideal positif. Berdasarkan perbandingan terhadap jarak relatifnya, susunan prioritas alternatif bisa dicapai. Metode ini banyak digunakan untuk menyelesaikan pengambilan keputusan. Hal ini disebabkan konsepnya sederhana, mudah dipahami, komputasinya efisien dan memiliki kemampuan mengukur kinerja relatif dan alternatifalternatif keputusan :

\section{Langkah-langkah Metode TOPSIS ${ }^{5}$.}

1. membangun normalized decision matrix

Elemen $\mathrm{r}_{\mathrm{ij}}$ hasil dari normalisasi decision matrix $\mathrm{R}$ dengan metode Euclidean length of a vector adalah :

Dimana :

$$
\mathrm{rij}_{\mathrm{i}}=\frac{X_{i j}}{\sqrt{\sum_{i}^{m}=1 x_{i j}^{2}}}
$$

$\mathrm{rij}_{\mathrm{ij}}=$ hasil dari normalisasi matriks keputusan $\mathrm{R}$ 
Xij $=$ Pengukuran pilihan dari alternatif ke-i dan kriteria ke-i

$\mathrm{i}=1,2,3, \ldots, \mathrm{m}$;

$\mathrm{j}=1,2,3, \ldots, \mathrm{n}$;

2. membangun weighted normalized decision matrix Dengan bobot $\mathrm{W}=(\mathrm{W} 1, \mathrm{~W} 2, \ldots, \mathrm{Wn})$, maka normalisasi bobot matrikx $\mathrm{V}$ adalah :

$$
V=\left[\begin{array}{ccc}
w_{11} r_{11} & \cdots & w_{1 n} r_{1 n} \\
\vdots & \ddots & \vdots \\
w_{m 1} r_{m 1} & \cdots & w_{n m} r_{n m}
\end{array}\right]
$$

3. menentukan solusi ideal positif dan solusi ideal negative

Solusi ideal positif dinotasikan dengan $\mathrm{A}+$ dan solusi ideal negatif dinotasikan dengan $\mathrm{A}-$, sebagai berikut :

$\mathrm{A}+=\left\{\left(\max V_{\mathrm{ijj}}\right)\left(\min V_{\mathrm{ijj}} \mid \mathrm{j} \in J\right), \mathrm{i}=, \ldots 3,2,1 \mathrm{~m}\right\}=\{\mathrm{V}+\mathrm{V}+21,, \mathrm{Vm}+\}$

$\mathrm{A}+=\left\{\left(\max V_{\mathrm{ij}}\right)\left(\operatorname{minV}_{\mathrm{ij}} \mathrm{j} j \in J\right), \mathrm{i}=, \ldots 3,2,1 \mathrm{~m}\right\}=\{\mathrm{V}+\mathrm{V}+21,, \mathrm{Vm}-\}$

Dimana :

Vij = elemen matriks $\mathrm{V}$ baris ke-i dan kolom ke $\mathbf{J}=\{\mathrm{j}=1,2,3, \ldots, \mathrm{n}$ dan $\mathrm{j}$ berhubungan dengan benefit criteria\}

$\mathrm{A}+=$ Solusi ideal positif $\mathrm{A}-=$ solusi ideal negatif

$\mathbf{J}=\{\mathrm{j}=1,2,3, \ldots, \mathrm{n}$ dan $\mathrm{j}$ berhubungan dengan cost criteria\}

\section{Menghitung separasi}

Separation measure ini merupakan pengukuran jarak dari suatu alternatif ke solusi ideal positif dan solusi ideal negatif perhitungan matematisnya adalah sebagai berikut :

$S_{i}=\sqrt{\sum_{j=1}^{n}\left(v_{i j}-v_{j}^{+}\right)^{2}}$, Dengan $\mathrm{i}=1,2,3, \ldots, \mathrm{m}$

Dimana :

$\mathrm{J}=\{\mathrm{j}=1,2,3, \ldots, \mathrm{n}$ dan $\mathrm{j}$ merupakan benefit criteria $\}$

$\mathrm{J}^{\prime}=\{\mathrm{j}=1,2,3, \ldots, \mathrm{n}$ dan $\mathrm{j}$ merupakan cost criteria $\}$

$\mathrm{Si}+=$ jarak ke solusi ideal positif

Separation measure untuk solusi ideal negative

$S_{i}=\sqrt{\sum_{j=1}^{n}\left(v_{i j}-v_{j}{ }^{-}\right)^{2}}$, Dengan $1=1,2,3, \ldots, \mathrm{m}$

Dimana : $\mathrm{S}_{\mathrm{i}}$

$\mathbf{J}=\{\mathrm{j}=1,2,3, \ldots, \mathrm{n}$ dan $\mathrm{j}$ merupakan benefit criteria $\}$

$\mathrm{J}^{\prime}=\{\mathrm{j}=1,2,3, \ldots \mathrm{n}$ dan $\mathrm{j}$ merupakan cost criteria $\}$

$\mathrm{Vij}=$ elemen matriks $\mathrm{V}$ baris ke-i dan kolom ke $\mathrm{J}$ $\{\mathrm{j}=1,2,3, \ldots, \mathrm{n}$ dan $\mathrm{j}$ berhubungan dengan benefit kriteria.

5. menghitung kedekatan relatif terhadap solusi ideal.

Kedekatan relatif dari alternatif $\mathrm{A}+$ dengan solusi ideal A- direpresentasikan dengan :

$$
C_{i}=\frac{s_{i}}{s_{j}^{-}+s_{i}^{+}}
$$

Dimana : $0<C_{i}^{+}<1$ dan $i=1,2,3 \ldots, \mathrm{m}$

6. Merangking alternative

Alternatif dapat diranking berdasarkan urutasn $\mathrm{C}^{*} \mathrm{i}$, maka dari itu, alternatif terbaik adalah salah satu yang berjarak terpendek terhadap solusi ideal dan berjarak terjauh dengan solusi ideal negative.

\section{METODE PENELITIAN}

Waktu dan Tempat pengumpulan data dan penelitian dilaksanakan di Dinas Pekerjaan Umum dan Penataan Ruang Provinsi Bengkulu. Metode pengumpulan data yang digunakan adalah sebagai berikut :

1. Wawancara (interview)

Wawancara merupakan suatu teknik pengumpulan data dengan jalan mengadakan komunikasi dengan sumber data. Komunikasi tersebut dilakukan dengan dialog (tanya jawab) secara lisan. Baik langsung maupun tidak langsung. Wawancara dilakukan terhadap karyawan bagian proyek pada dinas Pekerjaan Umum dan Penataan Ruang

2. Observasi (Pengamatan)

Observasi adalah metode pengumpulan data melalui pengamatan langsung atau peninjauan secara langsung, yaitu mengidentifikasi alternatif dan kriteria yang menentukan pemenangan tender proyek pada Dinas Pekerjaan Umum dan Penataan Ruang

3. Studi Pustaka

Metode studi pustakaan adalah cara pengambilan data dengan cara mengumpulkan konsep dan teori dari jurnal. Literatur, internet, majalah dan lainlain yang berhubungan dengan topik yang sesuai dengan penelitian yang sedang dilakukan.

\section{A. DESAIN SISTEM}

Implementasi Metode TOPSIS

Dalam menentukan pemenangan tender pada Dinas Pekerjaan Umum Penataan Ruang Bengkulu dilakukan dengan cara sebagai berikut :

1. Menentukan rating kepentingan untuk setiap kriteria.

Langkah yang dilakukan yaitu memberikan bobot terhadap setiap kriteria yang mempengaruhi keputusan. Bobot didapatkan dari data penelitian Dinas Pekerjaan Umum Penataan Ruang Provinsi Bengkulu.

Tabel 1 Bobot Kriteria

\begin{tabular}{|c|l|l|}
\hline & Kriteria & Bobot Kriteria \\
\hline 1. & Pengalaman & 30 \\
\hline 2. & Jumlah tenaga ahli & 20 \\
\hline 3. & Peralatan & 10 \\
\hline 4. & $\begin{array}{l}\text { Pernah bekerja sama dengan dinas } \\
\text { pekerjaan umum }\end{array}$ & 10 \\
\hline 5. & Gred Perusahaan & 30 \\
\hline
\end{tabular}

2. Menentukan rating kecocokan setiap alternatif dengan setiap kriteria dinilai dengan 1 sampai 5, berikut table skor kriteria yaitu :

Tabel 2 Skor kriteria

\begin{tabular}{|c|l|c|}
\hline Kriteria & \multicolumn{1}{|c|}{ Data awal } & Rangking \\
\hline Pengalaman (tahun) & $1-5$ & 1 \\
\cline { 2 - 3 } & $6-10$ & 2 \\
\cline { 2 - 3 } & $11-15$ & 3 \\
\cline { 2 - 3 } & $16-20$ & 4 \\
\cline { 2 - 3 } & $21-25$ & 5 \\
\hline
\end{tabular}




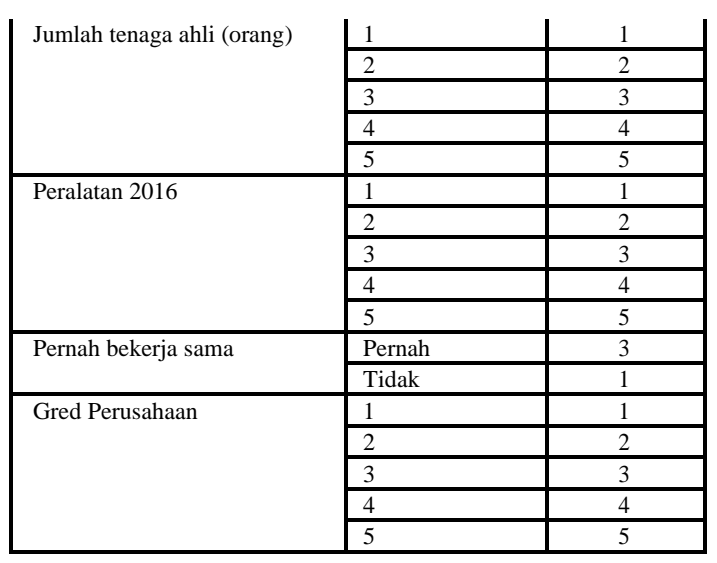

3. Membangun Matrix ternormalisasi

Setelah menentukan skor kriteria, selanjutnya menghitung nilai ternormalisasi dari tabel matriks keputusan.

Tabel 3 Matriks Ternormalisasi

\begin{tabular}{|c|c|c|c|c|c|}
\hline & $\begin{array}{c}\text { Pengalaman } \\
\text { (tahun) }\end{array}$ & $\begin{array}{c}\text { Jumlah } \\
\text { tenaga ahli } \\
\text { (orang) }\end{array}$ & Peralatan & $\begin{array}{c}\text { Pernah } \\
\text { bekerja } \\
\text { sama }\end{array}$ & $\begin{array}{c}\text { Gred } \\
\text { Perusahaan }\end{array}$ \\
\hline A1 & $\mathrm{X} 11$ & $\mathrm{X} 12$ & $\mathrm{X} 13$ & $\mathrm{X} 14$ & $\mathrm{X} 15$ \\
\hline $\mathrm{A} 2$ & $\mathrm{X} 21$ & $\mathrm{X} 22$ & $\mathrm{X} 23$ & $\mathrm{X} 24$ & $\mathrm{X} 25$ \\
\hline $\mathrm{A} 3$ & $\mathrm{X} 31$ & $\mathrm{X} 32$ & $\mathrm{X} 33$ & $\mathrm{X} 34$ & $\mathrm{X} 35$ \\
\hline $\mathrm{A} 4$ & $\mathrm{X} 41$ & $\mathrm{X} 42$ & $\mathrm{X} 43$ & $\mathrm{X} 44$ & $\mathrm{X} 45$ \\
\hline $\mathrm{A} 5$ & $\mathrm{X} 51$ & $\mathrm{X} 52$ & $\mathrm{X} 53$ & $\mathrm{X} 54$ & $\mathrm{X} 55$ \\
\hline
\end{tabular}

Pada table skor kriteria, rumus X11,..., X55 menyatakan performansi alternatif dengan acuan kriteria adalah data skor kriteria untuk setiap alternatif. Di mana : Xij adalah performansi alternatif ke i untuk kriteria ke j.

$A i(\mathrm{i}=1,2,3, \ldots, \mathrm{m})$ adalah alternatif-alternatif yang mungkin. $X j(\mathrm{j}=1,2,3, \ldots, \mathrm{n})$ adalah criteria. Hasil matriks keputusan yang dibentuk dari table data awal untuk setiap alternative dapat disajikan pada table matriks keputusan berikut :

Tabel 4 Matriks Keputusan

\begin{tabular}{|c|c|c|c|c|c|}
\hline $\begin{array}{c}\text { Nama } \\
\text { Perusahaan }\end{array}$ & $\begin{array}{c}\text { Pengalaman } \\
\text { (tahun) }\end{array}$ & $\begin{array}{c}\text { Jumlah } \\
\text { tenaga } \\
\text { ahli } \\
\text { (orang) }\end{array}$ & Peralatan & $\begin{array}{c}\text { Pernah } \\
\text { Bekerja } \\
\text { sama }\end{array}$ & $\begin{array}{c}\text { Gred } \\
\text { Perusahaan }\end{array}$ \\
\hline 1 & 10 th (2) & 5 & 2 & 1 & 3 \\
\hline 2 & 12 th $(3)$ & 3 & 2 & 3 & 3 \\
\hline 3 & 10 th (2) & 4 & 3 & 3 & 5 \\
\hline 4 & $15^{\text {th }}(3)$ & 3 & 3 & 3 & 5 \\
\hline 5 & 15 th $(3)$ & 3 & 4 & 3 & 4 \\
\hline
\end{tabular}

Setelah matriks keputusan dan bobot altrnatif dibuat, selanjutnya adalah membuat matriks keputusan yang ternormalisasi $\mathrm{R}$ yang fungsinya untuk memperkecil range data. Adapun elemen-elemennya telah ditentukan dengan rumus :

$$
r_{11}=\frac{x_{11}}{\sqrt{x_{11}+x_{21}+x_{31}+x_{41}+x_{51}}}
$$

Nilai Pembagi X1 $=\sqrt{2^{2}+3^{2}+2^{2}+3^{2}+3^{2}}=5,92$ Sehingga nilai ternormalisasi di atas disajikan dalam table berikut :
Tabel 5 Nilai Ternormalisasi

\begin{tabular}{|r|c|c|c|c|c|}
\hline & Pengalaman & Tenaga ahli & Peralatan & Kerja Sama & Gred \\
\hline 1 & 0,33806 & 0,60634 & 0,30861 & 0,16440 & 0,32733 \\
\hline 2 & 0,50709 & 0,36380 & 0,30861 & 0,49320 & 0,32733 \\
\hline 3 & 0,33806 & 0,48507 & 0,46291 & 0,49320 & 0,54554 \\
\hline 4 & 0,50709 & 0,36380 & 0,46291 & 0,49320 & 0,54554 \\
\hline 5 & 0,50709 & 0,36380 & 0,61721 & 0,49320 & 0,43644 \\
\hline
\end{tabular}

4. Membangun matrix ternormalisasi terbobot Setelah itu nilai $r$ dari hasil ternormalisasi dikalikan dengan bobot setiap rangking skor kritera nilai $\mathrm{V}$ ditunjukkan sebagai nilai ternormalisasi terbobot.

Tabel 6 Ternormalisasi Terbobot

\begin{tabular}{|c|c|c|c|c|c|}
\hline & Pengalaman & Tenagaahli & Peralatan & $\begin{array}{c}\text { Kerja } \\
\text { Sama }\end{array}$ & Gred \\
\hline 1 & W1.r11 & W2.r12 & W3.r13 & W4.r14 & W5.r15 \\
\hline 2 & W1.r21 & W2.r22 & W3.r23 & W4.r24 & W5.r25 \\
\hline 3 & W1.r31 & W2.r23 & W3.r33 & W4.r34 & W5.r35 \\
\hline 4 & W1.r41 & W2.r24 & W3.r43 & W4.r44 & W5.r45 \\
\hline 5 & W1.r51 & W2.r25 & W3.r53 & W4.r54 & W5.r55 \\
\hline
\end{tabular}

$\mathrm{V} 11=\mathrm{W} 1 \times \mathrm{r} 11=3 \times 0,33806=1,01419$

$\mathrm{V} 21=\mathrm{W} 1 \times \mathrm{r} 21=3 \times 0,50709=1,52128$

$\mathrm{V} 31=\mathrm{W} 1 \times \mathrm{r} 31=3 \times 0,33806=1,01419$

$\mathrm{V} 41=\mathrm{W} 1 \times \mathrm{r} 41=3 \times 0,50709=1,52128$

$\mathrm{V} 51=\mathrm{W} 1 \times \mathrm{r} 51=3 \times 0,50709=1,52128$

$\mathrm{V} 12=\mathrm{W} 2 \times \mathrm{r} 12=2 \times 0,60634=1,21268$

$\mathrm{V} 22=\mathrm{W} 2 \times \mathrm{r} 22=2 \times 0,36380=0,72761$

$\mathrm{V} 32=\mathrm{W} 2 \times \mathrm{r} 32=2 \times 0,48507=0,97014$

$\mathrm{V} 42=\mathrm{W} 2 \times \mathrm{r} 42=2 \times 0,36380=0,72761$

$\mathrm{V} 52=\mathrm{W} 2 \times \mathrm{r} 52=2 \times 0,36380=0,72761$

$\mathrm{V} 13=\mathrm{W} 3 \times \mathrm{r} 13=1 \times 0,30861=0,30861$

$\mathrm{V} 23=\mathrm{W} 3 \times \mathrm{r} 23=1 \times 0,30861=0,30861$

$\mathrm{V} 33=\mathrm{W} 3 \times \mathrm{r} 33=1 \times 0,46291=0,46291$

$\mathrm{V} 43=\mathrm{W} 3 \times \mathrm{r} 43=1 \times 0,46291=0,46291$

$\mathrm{V} 53=\mathrm{W} 3 \times \mathrm{r} 53=1 \times 0,61721=0,61721$

$\mathrm{V} 14=\mathrm{W} 4 \times \mathrm{r} 14=1 \times 0,16440=0,16440$

$\mathrm{V} 24=\mathrm{W} 4 \times \mathrm{r} 24=1 \times 0,49320=0,49320$

$\mathrm{V} 34=\mathrm{W} 4 \times \mathrm{r} 34=1 \times 0,49320=0,49320$

$\mathrm{V} 44=\mathrm{W} 4 \times \mathrm{r} 44=1 \times 0,49320=0,49320$

$\mathrm{V} 54=\mathrm{W} 4 \times \mathrm{r} 54=1 \times 0,49320=0,49320$

$\mathrm{V} 15=\mathrm{W} 5 \times \mathrm{r} 15=3 \times 0,32733=0,98198$

$\mathrm{V} 25=\mathrm{W} 5 \times \mathrm{r} 25=3 \times 0,32733=0,98198$

$\mathrm{V} 35=\mathrm{W} 5 \times \mathrm{r} 35=3 \times 0,54554=1,63663$

$\mathrm{V} 45=\mathrm{W} 5 \times \mathrm{r} 45=3 \times 0,54554=1,63663$

$\mathrm{V} 55=\mathrm{W} 5 \times \mathrm{r} 55=3 \times 0,43644=1.30931$

Tabel 7 Nilai Ternormalisas Terbobot

\begin{tabular}{|c|r|r|r|c|c|}
\hline & Pengalaman & Tenaga ahli & Peralatan & $\begin{array}{c}\text { Kerja } \\
\text { Sama }\end{array}$ & Gred \\
\hline 1 & 1,01419 & 1,21268 & 0,30861 & 0,1644 & 0,98198 \\
\hline 2 & 1,52128 & 0,72761 & 0,30861 & 0,4932 & 0,98198 \\
\hline 3 & 1,01419 & 0,97014 & 0,46291 & 0,4932 & 1,63663 \\
\hline 4 & 1,52128 & 0,72761 & 0,46291 & 0,4932 & 1,63663 \\
\hline 5 & 1,52128 & 0,72761 & 0,61721 & 0,4932 & 130.931 \\
\hline
\end{tabular}

5. Menentukan solusi ideal positif dan solusi ideal negative

Menentukan splusi ideal positif dan solusi ideal negative dengan cara memilih niali tertinggi dari nilai 
ternormalisasi terbobot untuk mencari solusi ideal positif yang dilambangkan dengan $\mathrm{A}^{+}$dan nilai terkecil sebagai nilai ideal negative yang dilambangkan $\mathrm{A}^{-}$.

Tabel 8 Solusi ideal positif dan ideal negatif

\begin{tabular}{|c|c|}
\hline Positif & Negatif \\
\hline 1,52128 & 1,01419 \\
\hline 1,21268 & 0,72761 \\
\hline 0,61721 & 0,3086 \\
\hline 0,4932 & 0,1644 \\
\hline 1,63663 & 0,98198 \\
\hline
\end{tabular}

6. Menentukan jarak Solusi

Dari hasil perhitungan jarak solusi, didapatkan hasil yang akan dipaparkan pada table berikut :

Tabel 9 Hasil Jarak Solusi Positif

\begin{tabular}{|c|c|}
\hline Alternatif & $\mathrm{S}^{+}$ \\
\hline 1 & 0,9429 \\
\hline 2 & 0,87127 \\
\hline 3 & 0,5829 \\
\hline 4 & 0,50902 \\
\hline 5 & 0,58518 \\
\hline
\end{tabular}

Tabel 10 Hasil Perhitungan Kedekatan Relatif

\begin{tabular}{|c|c|}
\hline Alternatif & C+ \\
\hline 1 & 0,33969 \\
\hline 2 & 0,40956 \\
\hline 3 & 0,57448 \\
\hline 4 & 0,63982 \\
\hline 5 & 0,56284 \\
\hline
\end{tabular}

Hasil dari perhitungan jarak solusi akan diurutkan dari nilai terbesar ke nilai terkecil. Nilai terbesar adalah solusi terbaik.

Tabel 11 Hasil Ranking

\begin{tabular}{|c|c|}
\hline Kontraktor & Ranking \\
\hline 4 & 0,63982 \\
\hline 3 & 0,57448 \\
\hline 5 & 0,56284 \\
\hline 2 & 0,40956 \\
\hline 1 & 0,33969 \\
\hline
\end{tabular}

Dari perhitungan dengan metode TOPSIS telah merekomendasikan perusahaan no 3 sebagai pemenang tender dengan nilai tertinggi yaitu 0,63982

\section{B. DIAGRAM KONTEKS}

Diagram konteks adalah diagram yang menggambarkan system secara umum. Diagram konteks merupakan alat bantu perancangan yang merupakan alat bantu perancangan yang merupakan bagian dari Data Flow Diagram (DFD) yang memperlihatkan bagian-bagian atau entitas-entitas yang terlibat di dalam system dan bagaimana entitasentitas tersebut berhubungan. Diagram ini memperlihatkan pengalihan data di dalam system dan melebarkan konseptualitas system yang memungkinkan. Diagram ini adalah tingkatan tertinggi dalam aliran data dan hanya memuat satu proses secara keseluruhan. Gambar 1 dibawah ini memperlihatkan bagaimana system pendukung keputusan untuk proses menentukan pemenang tender pada Dinas Pekerjaan Umum dan Penataan Ruang Provinsi Bengkulu.

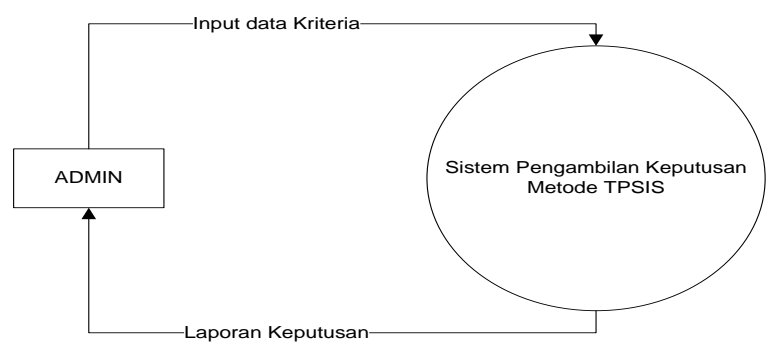

Gambar 1 Diagram Konteks

Pada diagram konteks ini dapat dilihat masing-masing hubungan entitas terhadap system secara garis besar, serta alur-alur yang menunjukkan dan menggambarkan proses serta informasi yang didapat oleh masing-masing entitas.

\section{DFD (Data Flow Diagram)}

Data Flow Diagram (DFD) adalah alat pembuatan model yang memungkinkan system menggambarkan bahwa system sebagai suatu jaringan proses fungsional yang dihubungkan satu sama lain dengan alur data, baik secara manual maupun komputerisasi. GAmbar 2 dibawah ini memperlihatkan data flow diagram (DFD) menggambarkan bagaimana system pendukung keputusan untuk proses menentukan pemenang tender pada Dinas Pekerjaan Umum dan Penataan Ruang Provinsi Bengkulu.

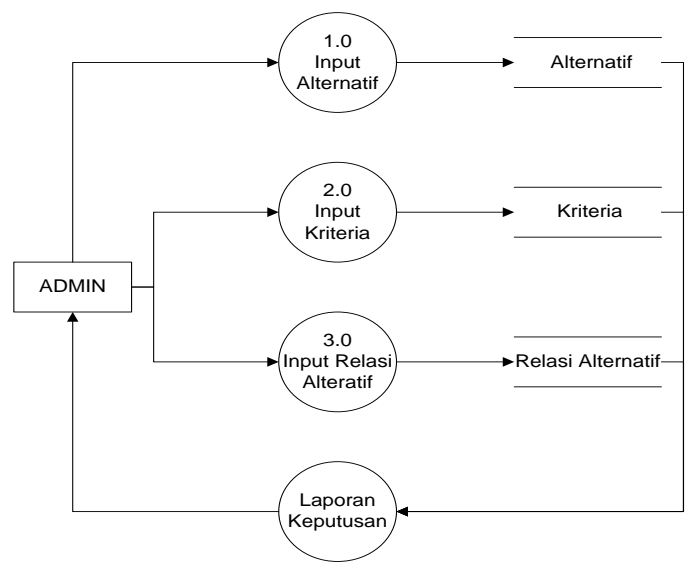

Gambar 2 DFD (Data Flow Diagram)

\section{ERD (Entity Relationship Diagram)}

Entity Relationship Diagram (ERD) menggambarkan kebutuhan inormasi atau jenis informasi yang akan disimpan dalam database. Teknik pemodelan data dalam system pendukung keputusan ini dapat digunakan untuk menggambarkan setiap klasifikasi dari istilah yang digunakan dan hubungan antar informasi. 


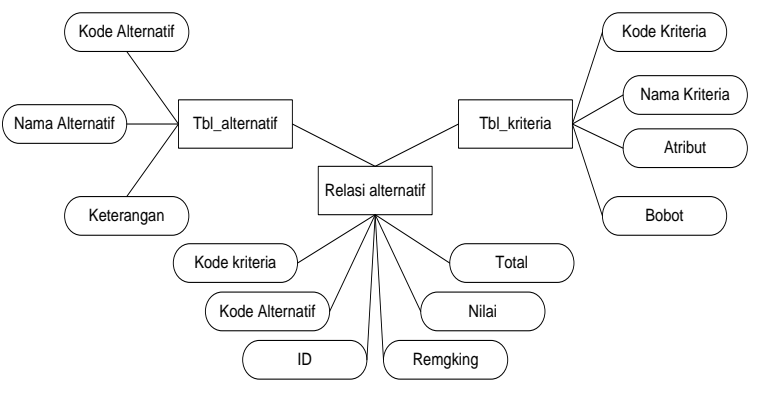

Gambar 3 ERD (Entity Relationship Didagram)

\section{IV.Hasil dan Pembahasan}

Tampilan Dekstop Sistem Pendukung Keputusan Menu Awal

1. Tampilan Halaman Login

Apabila Program tersebut diaktifkan, maka Pada layar akan terlihat tampilan login. Pada tampilan halaman login ini, user menginput username dan password untuk masuk ke halaman Sistem Pendukung Keputusan Pemenang Tender Dinas PUPR.

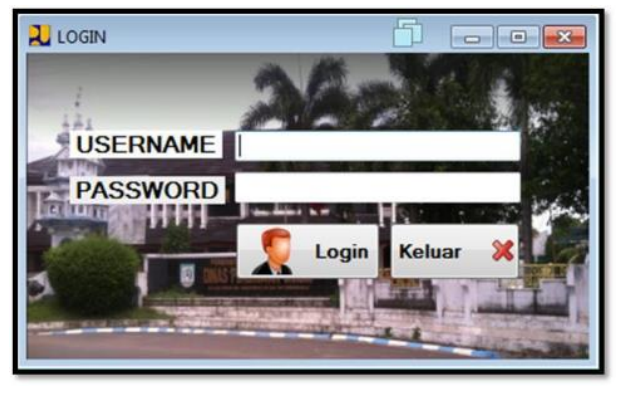

Gambar 4 Tampilan Login

\section{Tampilan Halaman Menu Utama}

Halaman ini merupakan menu awal setelah login dilakukan. Pada menu utama terdapat berbagai pilihan menu untuk melanjutkan proses aplikasi. Menu Utama berisi master data untuk input, perhiungan, dan laporan yang akan membantu dalam penggunaan aplikasi

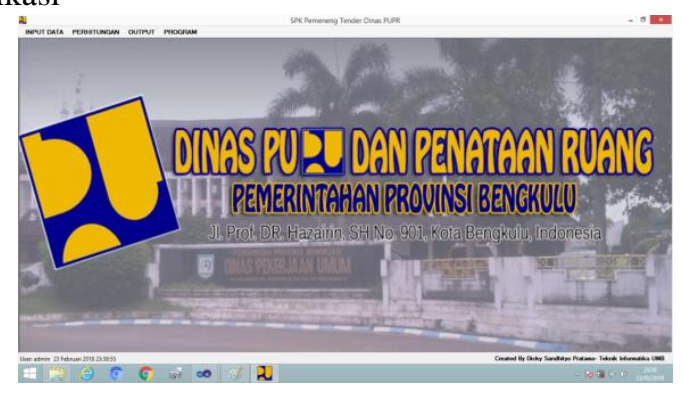

Gambar 5 Menu Utama

\section{Menu Master Data}

1. Tampilan Entry Data Alternatif

Input data alternatif adalah form yang berisi tentang perusahaan yang mengajukan diri dalam tender di Dinas Pekerjaan Umum Provinsi Bengkulu yang akan di pilih. Data alternatif ini berisi kode alternatif, nama alternatif dan keterangan. Informasi ini yang akan digunakan nanti dalam pemilihan pemenangan tender.

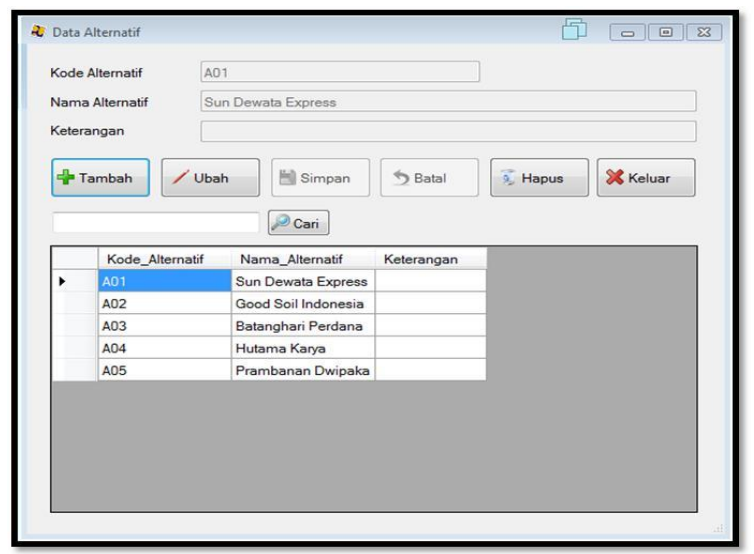

Gambar 6 Data Alternatif

\section{Data Kriteria}

input data kriteria adalah form yang berisi tentang kriteria yang mempengaruhi dalam pemilihan pemenang tender proyek pada Dinas Pekerjaan Umum Provinsi Bengkulu. Data ini berisi kode kriteria, nama kriteria, atribut dan bobot. Informasi ini yang akan mempengaruhi dalam pengamblan keputusan dalam pemilihan tender.

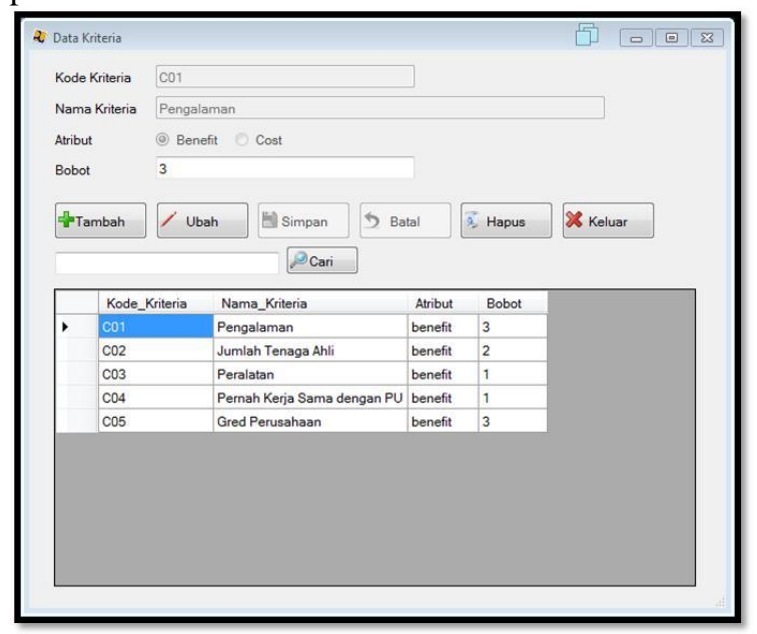

Gambar 7. Data Kriteria

\section{Relasi Nilai Bobot}

Nilai bobot adalah form yang berisi table kecocokan antara kriteria dan alternatif. Nilai tersebut yang akan digunakan untuk proses TOPSIS selanjutnya. Data ini berisi nilai bobot dari alternatif dan kriteria yang menjadi nilai perhitungan TOPSIS. Informasi ini yang akan mempengaruhi pengambilan keputusan dalam pemilihan pemenangan tender proyek di Dinas Pekerjaan Umum Provinsi Bengkulu. 


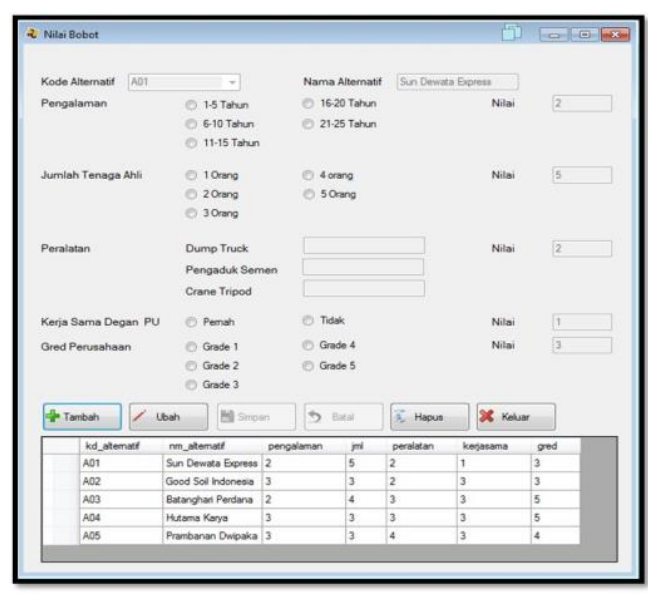

Gambar 8 Nilai Bobot

Menu Perhitungan

Menu perhitungan adalah form yang berisi proses perhitungan metode TOPSIS. Terdiri dari hasil analisa, Normalisasi, Normalisasi Terbobot, Solusi Ideal, Jarak Solusi dan Ranking.

1. Tampilan hasil analisa

Hasil analisa menampilkan nilai bobot sebelumnya untuk dapat dilanjutkan ke proses TOPSIS berikutnya.

\begin{tabular}{|c|c|c|c|c|c|c|}
\hline & Kode & \multicolumn{2}{|l|}{ Nama } & \multicolumn{2}{|l|}{$\mathrm{C} 01$} & $\mathrm{C02}$ \\
\hline \multirow[t]{5}{*}{ - } & A01 & \multicolumn{2}{|c|}{ Sun Dewata Express } & \multicolumn{2}{|c|}{0.338061701891407} & 0.606339062590832 \\
\hline & A02 & \multicolumn{2}{|c|}{ Good Soil Indonesia } & \multicolumn{2}{|c|}{0,50709255283711} & 0.363803437554499 \\
\hline & A03 & \multicolumn{2}{|c|}{ Batanghari Perdana } & \multicolumn{2}{|c|}{0,338061701891407} & 0.485071250072666 \\
\hline & A04 & \multicolumn{2}{|c|}{ Hutama Karya } & \multicolumn{2}{|c|}{0.50709255283711} & 0.363803437554499 \\
\hline & A05 & \multicolumn{2}{|c|}{ Prambanan Dwipaka } & \multicolumn{2}{|c|}{0,50709255283711} & 0,363803437554499 \\
\hline \multicolumn{2}{|c|}{$\mathrm{CO3}$} & & \multicolumn{2}{|l|}{$\mathrm{CO} 4$} & \multicolumn{2}{|l|}{$\mathrm{C} 05$} \\
\hline \multicolumn{3}{|c|}{0,308606699924184} & \multicolumn{2}{|c|}{0.164398987305357} & \multicolumn{2}{|c|}{0,327326835353989} \\
\hline \multicolumn{3}{|c|}{0,308606699924184} & \multicolumn{2}{|c|}{0.493196961916072} & \multicolumn{2}{|c|}{0,327326835353989} \\
\hline \multicolumn{3}{|c|}{0,462910049886276} & \multicolumn{2}{|c|}{0,493196961916072} & \multicolumn{2}{|c|}{0,545544725589981} \\
\hline \multicolumn{3}{|c|}{0,462910049886276} & \multicolumn{2}{|c|}{0.493196961916072} & \multicolumn{2}{|c|}{0.545544725589981} \\
\hline \multicolumn{3}{|c|}{0.617213399848368} & \multicolumn{2}{|c|}{0.493196961916072} & \multicolumn{2}{|c|}{0.436435780471985} \\
\hline
\end{tabular}

Gambar 9. Hasil Analisa

\section{Normalisasi}

Normalisasi berisi nilai perhitungan Normalisasi yang akan dilanjutkan ke tahap perhitungan TOPSIS berikutnya

\begin{tabular}{|c|c|c|c|c|c|c|}
\hline & Kode & \multicolumn{2}{|l|}{ Nama } & \multicolumn{2}{|l|}{$\mathrm{C} 01$} & $\mathrm{CO2}$ \\
\hline \multirow[t]{5}{*}{ • } & A01 & \multicolumn{2}{|c|}{ Sun Dewata Express } & \multicolumn{2}{|c|}{10.1418510567422} & 12,1267812518166 \\
\hline & A02 & \multicolumn{2}{|c|}{ Good Soil Indonesia } & \multicolumn{2}{|c|}{15,2127765851133} & 7.27606875108999 \\
\hline & $\mathrm{A} 03$ & \multicolumn{2}{|c|}{ Batanghari Perdana } & \multicolumn{2}{|c|}{10,1418510567422} & 9.70142500145332 \\
\hline & A04 & \multicolumn{2}{|c|}{ Hutama Karya } & \multicolumn{2}{|c|}{15,2127765851133} & 7.27606875108999 \\
\hline & A05 & \multicolumn{2}{|c|}{ Prambanan Dwipaka } & \multicolumn{2}{|c|}{15.2127765851133} & 7.27606875108999 \\
\hline \multicolumn{2}{|c|}{$\mathrm{CO} 3$} & \multicolumn{3}{|c|}{$\mathrm{CO} 4$} & \multicolumn{2}{|l|}{$\mathrm{CO5}$} \\
\hline \multicolumn{3}{|c|}{3,08606699924184} & \multicolumn{2}{|c|}{1.64398987305357} & \multicolumn{2}{|c|}{9,81980506061966} \\
\hline \multicolumn{3}{|c|}{3.08606699924184} & \multicolumn{2}{|c|}{4.93196961916072} & \multicolumn{2}{|c|}{9,81980506061966} \\
\hline \multicolumn{3}{|c|}{4.62910049886276} & \multicolumn{2}{|c|}{4.93196961916072} & \multicolumn{2}{|c|}{16.3663417676994} \\
\hline \multicolumn{3}{|c|}{4.62910049886276} & \multicolumn{2}{|c|}{4.93196961916072} & \multicolumn{2}{|c|}{16.3663417676994} \\
\hline \multicolumn{3}{|c|}{6,17213399848368} & \multicolumn{2}{|c|}{4.93196961916072} & \multicolumn{2}{|c|}{13.0930734141595} \\
\hline
\end{tabular}

Gambar 10. Normalisasi

3. Normalisasi Terbobot
Normalisasi terbobot berisi nilai perhitungan normalisasi terbobot dengan mengalihkan nilai normalisasi dengan bobot kriteria.

\begin{tabular}{l|l|l} 
& C01 & C02 \\
\hline Positif & 15,2127765851133 & 12,1267812518166 \\
\hline Negatif & 10,1418510567422 & 7,27606875108999 \\
\hline
\end{tabular}

\begin{tabular}{|l|l|l|}
\hline C03 & C04 & C05 \\
\hline 6.17213399848368 & 4.93196961916072 & 16.3663417676994 \\
\hline 3.08606699924184 & 1.64398987305357 & 9.81980506061966 \\
\hline
\end{tabular}

Gambar 11 Normalisasi Terbobot

4. Solusi Ideal

Solusi Ideal berisi nilai solusi ideal untuk selanjutnya diproses pada perhitungan TOPSIS

\begin{tabular}{|l|l|l|l|} 
Kode & Nama & Positif & Negatif \\
\hline A01 & Sun Dewata Express & 9.42900041924111 & 4.85071250072666 \\
\hline A02 & Good Soil Indonesia & 8.7126554015213 & 6.04359963309091 \\
\hline A03 & Batanghari Perdana & 5.82903002534852 & 7.86964160493237 \\
\hline A04 & Hutama Karya & 5.09022240630586 & 9.04230013675679 \\
\hline A05 & Prambanan Dwipaka & 5,85181146987765 & 7.53413510385842 \\
\hline
\end{tabular}

Gambar 12. Solusi Ideal

\section{Jarak Solusi}

Jarak solusi ini berisi nilai jarak solusi untuk selanjutnya di proses pada perhitungan TOPSIS

\begin{tabular}{|l|l|l|} 
Kode & Nama & Total \\
\hline A04 & Hutama Karya & 0,639822091859705 \\
\hline A03 & Batanghari Perdana & 0,574482097047756 \\
\hline A05 & Prambanan Dwipaka & 0,562839173334278 \\
\hline A02 & Good Soil Indonesia & 0,409561885377765 \\
\hline A01 & Sun Dewata Express & 0,339692578409175 \\
\hline \multicolumn{2}{|c|}{ Gambar 10. Jarak Solusi }
\end{tabular}

\section{Ranking}

Hasil ranking dari nilai terbesar atau yang paling mendekati 1 ke nilai yang lebih kecil. Nilai yang paling besar adalah rekomendasi untuk pemenangan tender proyek pada Dinas Pekerjaan Umum Provinsi Bengkulu

\section{Menu Output}

Menu output berisi informasi tentang hasil dari proses metode TOPSIS.Pada menu output ini menggunakan aplikasi Crystal Report 13

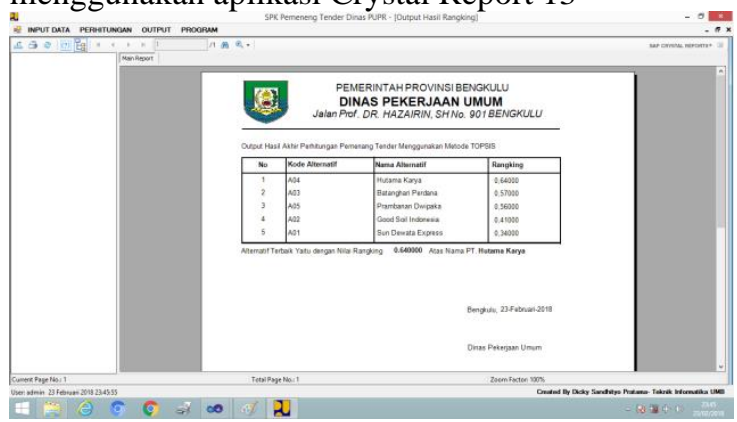

Gambar 13 Output Ranking Perhitungan 
Berdasarkan hasil pengujian diatas yang didapat dari pengujian data. Maka dapat disimpulkan bahwa Sistem Pendukung Keputusan ini sudah sesuai dengan tujuannya yaitu memudahkan pengguna dalam menentukan pemenang tender pada Dinas Pekerjaan Umum dan Penataan Ruang Provinsi Bengkulu.

\section{KESIMPULAN DAN SARAN}

Berdasarkan hasil pengamatan yang telah dilakukan melalui implementasi dan penyajian aplikasi pemilihan pemenang tender pada dinas Pekerjaan Umum Provinsi Bengkulu.

1. Metode TOPSIS dapat diterapkan pada Sistem Pendukung Keputusan pemilihan pemenangan tender proyek pada Dinas Pekerjaan Umum Provinsi Bengkulu.

2. Aplikasi Sistem Pendukung Keputusan Pemilihan pemenangan tender proyek pada Dinas Pekerjaan Umum Provinsi Bengkulu yang telah dibuat menggunakan metode TOPSIS dengan hasil yang akurat.

3. Aplikasi Sistem Pendukung Keputusan Pemilihan pemenang tender proyek ini dapat membantu pihak Dinas Pekerjaan Umum Provinsi Bengkulu dalam memilih pemenangan tender di Provinsi Bengkulu.

\section{Daftar Pustaka}

[1] Akhmad, Fadjar Siddiq (2012). Mrtode TOPSIS dalam Sistem Pengambilan Keputusan. Yogyakarta: Graha Ilmu.

[2] Tarigan. 2012. Sistem Pendukung Keputusan Menentukan Bibit Unggul Buah Stroberi Menggunakan Metode Topsis, Pelita Informatika budi dharma. Vol.VI No.2. hlm. 11

[3] Rohayani. April. 2013. Analisis Sistem Pendukung Keputusan Dalam Memilih Program Studi Menggunakan Metode Logika Fuzzy,Jurnal Sistem Informasi. Vol. 5, No. 1. hlm. 532-533

[4] Kurniasih.2013.Sistem Pendukung Keputusan Pemilihan Laptop Dengan Metode Topsis,Pelita Informatika Budi Darma. Volume III Nomor : 2

[5] Kusumadewi, Sri (2003). Artificial Intelligence Teknik dan Aplikasinya. Yogyakarta: Graha Ilmu

[6] Rohmat, Nur Ibrahim. 2012. Kriptografi Algoritma Des, Aes/Rijndael, Blowfish Untuk Keamanan Citra Digital Dengan Menggunakan Metode Discrete Wavelet Transformation $(D W T)$. Jurnal Computech \& Bisnis. STMIK Mardira Indonesia, Bandung 